\title{
Provenance, tectonic settings and depositional environmental records of the Cambrian Wuliuan (Miaolingian) Kunzam La (Parahio) Formation in the Sumna Valley, Spiti, NW Himalaya
}

\author{
Garry Singla ${ }^{1}$, Sajid $\mathrm{Ali}^{2}$, B.P. Singh ${ }^{1}$, O.N. \\ Bhargava $^{1}$, Ramanpreet Kaur ${ }^{1}$, S. Stopden ${ }^{1}$ \\ 123 \\ 1 Department of Geology, Panjab University, Chandigarh \\ (India) \\ 2 Birbal Sahni Institute of Paleogeosciences (BSIP), \\ Lucknow (India)
}

The Cambrian successions are globally well studied to infer the tectonic settings and depositional environments. However, such records from the Spiti basin in the Himalayan region are very rare and their tectonic settings and depositional environment still remain controversial. We present trace element and rare earth element (REEs) analysis of the Cambrian Wuliuan (Miaolingian) Kunzam La (Parahio) Formation from the Sumna Valley, Spiti (India). The trace elemental ratios of $\mathrm{Th} / \mathrm{Co}, \mathrm{Th} / \mathrm{Sc}, \mathrm{La} / \mathrm{Sc}$ and $\mathrm{Cr} / \mathrm{Th}$ show similar composition to that of upper continental crust and suggest sediments were derived from a felsic source that lie within the Indian craton. Furthermore, chondritenormalized REE patterns with enriched light rare earth elements (LREE), and almost flat heavy rare earth elements (HREE) and prominent negative Eu anomalies also suggest felsic source. The ternary La-Th-Sc discrimination diagram and binary $\mathrm{La} / \mathrm{Y}$ vs $\mathrm{Sc} / \mathrm{Cr}$ ratios plot show these sediments were deposited in cyclic passive and active margin settings. The selected trace element ratios such as $\mathrm{V} / \mathrm{Cr}, \mathrm{Ni} / \mathrm{Co}, \mathrm{Th} / \mathrm{U}$, $\mathrm{V} / \mathrm{V}+\mathrm{Ni}$ as well as positive $\mathrm{Ce}$ and $\mathrm{Eu}$ anomalies suggests oxidizing conditions were prevailing during the deposition. The concentration of $\mathrm{Y}, \mathrm{Zr}, \mathrm{Rb}$ elements indicate proximal, near-shore environment and a larger continental detrital deposits. Low REE $+Y$ concentration at Cambrian Series 2Miaolingian boundary indicates major transgressive event. 